\title{
In-service Preschool Teachers' Thoughts about Technology and Technology Use in Early Educational Settings
}

\author{
Nuri Kara \\ Girne American University, North Cyprus \\ Kursat Cagiltay \\ Middle East Technical University, Turkey
}

\begin{abstract}
The purpose of this study is to understand in-service preschool teachers' thoughts about technology and technology use in early educational settings. Semi-structured interviews were conducted with 18 in-service preschool teachers. These teachers were selected from public and private preschools. Convenient sampling was applied because teachers who were eager to attend the study were selected. Content analysis technique was used to analyze the data. Based on the content analysis, eleven main themes as to technology related views and practices of in-service preschool teachers emerged. Findings of the study indicated that the majority of in-service teachers had positive views about appropriate technology use in preschool education. Findings also showed that early educational settings need to be equipped with adequate technologies. Moreover, in-service preschool teachers emphasized that they expect to be supported by the preschool curriculum and several programs aiming at enhancing their technology use skills. Lastly, teachers were aware of not only the advantages of technology but also the potential disadvantages. Results of the study may help instructional designers, researchers and practitioners better integrate new technologies into preschool education.
\end{abstract}

Keywords: Preschool education; Preschool teachers; Technology; Technology use; Children; In-service teachers

\section{Introduction}

Teachers play a key role for young children in early educational settings since they build a direct communication with these children. Hence, the practices and attitudes of preschool teachers towards computer and other technologies may affect children's learning. Studies in the literature show that preschool teachers are in favor of introducing computers into early educational settings (Towns, 2010; Tsitouridou \& Vryzas, 2004). More specifically, teachers use computers in accordance with children's personal skills, styles and social demands to help them learn (Chen \& Chang, 2006). Similarly, "most teachers do recognize the contribution of the computer to the skills development of the young child, primarily in the intellectual and aesthetic fields and secondarily in the socio-emotional and psycho-motor fields" (Tsitouridou \& Vryzas, 2004 , p. 40). It can be concluded from these statements that teachers' practices and their beliefs toward computers in early educational settings are crucial to support children's learning. Since there has been an increase as to the number of studying new technologies besides computers in early childhood education (ECE) in the last few years (Bolstad, 2004), teachers' effects on 
children can play an important role in terms of not only computer use and integration but also the adaption of other kinds of technologies, such as smart toys, robotics and digital materials.

Since new technologies in early childhood education can enhance the effectiveness of educational practice, more research studies need to be carried out. Similar to this view, Mangen (2010) pointed out that detailed practice and use of information and communication technologies (ICT) in preschools need to be focused besides only offering new technologies to children. Bolstad (2004) listed research literature of ICT in five categories:

1. "effects" research;

2. investigations of children's behavior and interactions around computers;

3. research into children's experiences of ICT in early childhood education settings and at home;

4. research about practitioners' professional learning in, or through, ICT; and

5. case studies or exemplars of innovative use of ICT in early childhood education settings (p. 13).

Based on these categories, practices of technology use and interaction in early childhood settings are mostly considered in the research literature. Including preschool teachers, into the research studies can also enhance the quality and appropriateness of new technologies to be used in early childhood settings.

The major purpose of this study was to investigate in-service preschool teachers' thoughts about technology and technology use in early educational settings. Since today's children, in general, face with new kind of technologies, such as tablets, smartphones and similar devices in their daily life, understanding preschool teachers' views and approaches toward technology and technology use can play an important role to integrate these technologies into early educational settings. Hence, the main research question and sub questions were as follow:

What are in-service preschool teachers' thoughts about technology and technology use in early educational settings?

- What are the current technology practices of in-service preschool teachers?

- How the curriculum affect in-service preschool teachers' technology use?

- What are in-service preschool teachers' expectations regarding with technology use?

- What are the problems in-service preschool teachers encounter while using technology?

\section{Literature Review}

\section{Preschool Teachers and Technology}

Stipek and Byler (1997) declared that teachers of young children consider their primary goal as preparing children academically to the first grade and emphasizing basic skills. These teachers focus on increasing the capabilities of young children and developing cognitive, affective, psychomotor and social skills. Preschool teachers also take the main responsibilities in early educational settings. According to Stipek and Byler (1997), 
Teachers of young children make myriad decisions-about whether to emphasize basic skills; about the degree to which activities are child-versus teacherinitiated, structured or unstructured, completed alone or with peers; about how strict to be in managing the classroom; and so on (p. 305).

Early childhood teachers generally demonstrate child-centered beliefs (Isikoglu, Basturk \& Karaca, 2009). The preschool curriculum in Turkey also expects teachers to follow child-centered practices in learning environments (MoNE, 2013). Technology's active and dynamic role in early educational settings can provide alternative child-centered practices. Technology's capability of including children into several activities as active participants gives an opportunity to teachers to create child-centered learning environment. Since the curriculum allows teachers to provide rich and a variety of activities for children (MoNE, 2013), technology can be integrated into early educational settings to support child centered learning.

Since preschool teachers make several decisions in early educational settings, it is important to emphasize teachers' approaches and opinions. Information and Communication Technologies (ICT) use in early educational environments might also be affected by the teachers' views and intentions. Blackwell, Lauricella and Wartella (2014) found in their study that early childhood teachers' attitudes towards the role of technology are of great significance in terms of technology use. Kalaš (2010) affirms that ECE teachers support the educational value of ICT. Similarly, teachers of young children generally have positive attitudes or views towards the use and integration of new technologies (Marsh et al., 2005; Nikolopoulou \& Gialamas, 2009). Teachers' positive approaches toward new technologies in early educational environments can accelerate the integration of ICT. Teachers who believe the educational value of ICT can lead children to technology related activities and integrate these activities to the preschool curriculum.

Although the survey studies in the literature provide numerical results as to the number of computers or use frequency, these studies show little information about teachers' integration of computers for supporting the learning of young children (Chen \& Chang, 2006). There should be more studies investigating the current situation of preschool teachers in terms of technology integration and use in early educational settings. "To better prepare early childhood teachers for computer use, more information about their current skills and classroom practices is needed" (Chen \& Chang, 2006, p.169). Hence, investigating the current practices of preschool teachers can be an effective starting point for integrating new technologies into early educational environments.

The studies in Turkish literature have generally been based on survey research methodology, focusing on the attitudes and thoughts of early childhood teachers toward the use of technology, specifically computers (Kabadayi, 2006; Oguz, Ellez, Akamca, Kesercioglu, \& Girgin, 2011; Onkol, Zembat, \& Balat, 2011; Yurt \& Cevher-Kalburan, 2011). Although Gok, Turan and Oyman (2011) made a research about investigating the preschool teachers' views on usage of information technologies, the sample consisted of 10 teachers working at private schools and only focus group meetings were carried out to collect data. Based on the current studies in Turkish literature, it can be stated that the more detailed qualitative research studies should be conducted to understand the current practices and views of early childhood teachers. As Blackwell et al. (2014) declared, personal beliefs of early childhood teachers are of great significance in terms of technology use. Additionally, "in the classroom, teachers adapt computer use to accommodate children's varying levels of skills, different personal interests, 
and optimal social groupings". (Chen \& Chang, 2006, p. 181). Therefore, understanding the current practices, views and beliefs of early childhood teachers towards the use of technology can play a critical role to integrate new technologies since they are the main practitioners in early educational settings.

\section{Preschool Curriculum in Turkey}

As of 2013-2014 educational year, there are 26,698 schools giving early childhood education with 1,059,495 children and 63,327 teachers in Turkey (MoNE, 2014). "One of the major political issues in early childhood education in Turkey is to increase the schooling rate at this level because it is pretty high among EU countries (95\%) compared to Turkey (16\%)" (Atay-Turhan, Koc, Isiksal, \& Isiksal, 2009, p. 352). Another important issue as to early childhood education in Turkey is updating the preschool curriculum in specific time periods. The final curriculum was prepared by the Ministry of National Education in 2013 towards 36-72 months age children. The main titles presented in the curriculum are; (1) General purposes of national education, (2) The purpose of preschool education, (3) The main principles of preschool education, (4) The significance of preschool period, (5) Introduction to the preschool curriculum, (6) Developmental characteristics, objectives and indicators, (7) Planning and implementing of preschool education, and (8) Evaluation of preschool education (MoNE, 2013). Child based, play based, flexible, eclectic, and well balanced activities are some of the important characteristics of preschool education (MoNE, 2013). Additionally, discovery based learning, enhancing creativity, and experiencing real life situations also play very important role in preschool education.

Compared with the preschool curriculum developed in 2006, the major difference of new curriculum is to focus on enriching learning experiences of children. Although both of the curricula do not mention the term "technology" and "technology use", the new developed curriculum, at least, shows statements regarding of using materials and providing alternative stimulus to enrich learning experiences and educational environments. Objectives and explanations of different domains based on the different age groups compose the main part of the curriculum. Cognitive objectives, language objectives, social and affective objectives, psychomotor objectives and self-care objectives toward 36-48, 48-60 and 60-72 months age children are explained in the curriculum in a detailed way (MoNE, 2013). Since the preschool curriculum requires preschool teachers creating rich learning experiences for children and providing children centered flexible learning environment, it is important to investigate preschool teachers' thoughts about technology and technology related practices in early childhood education.

\section{Research Methodology}

\section{Participants}

Convenience sampling was the main sampling strategy to select and determine the participants. According to Marshall and Rossman (2011), "researchers' site selection and sampling often begin with accessible sites" (p. 107). Researchers, firstly, contacted with several public and private preschools in Ankara district of Turkey. After getting the required permission from the school managers to conduct interviews in their preschools, researchers requested in-service 
preschool teachers to conduct interviews for understanding their thoughts about technology and technology use. Finally, researchers went to preschools that teachers work and made interviews with them accepting to attend the study. In total, 6 public and 3 private preschools were selected to conduct interviews. Therefore, convenience sampling was mainly applied in this study to reach the volunteers.

18 preschool teachers participated interview sessions to understand their views toward technology and technology use. All teachers were women. Teachers who were eligible to attend the study and eager to share their views were selected from both public and private preschools (see Table 1). Teachers were coded like PT with a sequence number. All teachers declared that they use technology, mostly computers in their classrooms. Half of them showed a positive belief as to using technology in a competent way (see Table 1).

Table 1. Information about Interviewed Teachers

\begin{tabular}{|c|c|c|c|c|c|c|}
\hline No & Age & Education Level & School & $\begin{array}{l}\text { Teaching } \\
\text { experience } \\
\text { (year) }\end{array}$ & $\begin{array}{l}\text { Technology / } \\
\text { Computer Use at } \\
\text { School }\end{array}$ & $\begin{array}{l}\text { Belief as to } \\
\text { using } \\
\text { Technology } \\
\text { competently }\end{array}$ \\
\hline PT1 & 34 & Bs - ECE & Public & 13 & Yes & No \\
\hline PT2 & 37 & $\mathrm{Bs}-\mathrm{ECE}$ & Public & 14 & Yes & Yes \\
\hline PT3 & 39 & Bs - ECE & Public & 12 & Yes & No \\
\hline PT4 & 37 & $\mathrm{Bs}-\mathrm{ECE}$ & Public & 15 & Yes & No \\
\hline PT5 & 34 & $\mathrm{Bs}-\mathrm{ECE}$ & Public & 15 & Yes & No \\
\hline PT6 & 29 & Bs - ECE & Public & 9 & Yes & Yes \\
\hline PT7 & 29 & Bs - ECE & Private & 9 & Yes & Yes \\
\hline PT8 & 26 & Bs - ECE & Public & 4 & Yes & Yes \\
\hline PT9 & 29 & $\mathrm{Bs}-\mathrm{ECE}$ & Public & 7 & Yes & No \\
\hline PT10 & 32 & Ms - ECE & Public & 9 & Yes & No \\
\hline PT11 & 30 & Bs - ECE & Private & 9 & Yes & Yes \\
\hline PT12 & 30 & Ms - ECE & Public & 10 & Yes & No \\
\hline PT13 & 34 & Bs - ECE & Public & 14 & Yes & Yes \\
\hline PT14 & 24 & $\begin{array}{l}\text { Bs - Child } \\
\text { development }\end{array}$ & Private & 4 & Yes & Yes \\
\hline PT15 & 24 & Bs - ECE & Private & 4 & Yes & No \\
\hline PT16 & 29 & Bs - ECE & Public & 7 & Yes & Yes \\
\hline PT17 & 33 & Bs - ECE & Public & 8 & Yes & Yes \\
\hline PT18 & 26 & $\mathrm{Bs}-\mathrm{ECE}$ & Public & 4 & Yes & No \\
\hline
\end{tabular}

\section{Data Collection Instrument}

The purpose of the study was to understand in-service preschool teachers' thoughts about technology and technology use in early educational settings. Since understanding preschool teachers' views and practices require in-depth analysis, interviews were selected as the main data collection instrument of this study. Interviews could enable research to ask open-ended questions to better understand the thoughts of preschool teachers. According to Marshall and Rossman (2011), "interviews have particular benefits because an interview yields data in quantity quickly" (p. 145). In addition, interviews allow researcher to understand the 
interviewee's thinking (Bogdan \& Biklen, 2007). In the current study, semi-structured interviews were preferred. As Brenner (2006) stated, "a semi structured protocol has the advantage of asking all informants the same core questions with the freedom to ask follow-up questions that build on the responses received" (p. 362). Semi-structured interviews were conducted to understand in-service preschool teachers' thoughts about technology and technology use in early educational settings.

An interview protocol was used during interview sessions. The interview protocol included three main categories, namely interview plan, demographic questions and questions as to content and process. The researcher explained the purpose of the study and gave information about the interview process in the plan category. Interviewees' demographic information was gathered in the category of demographic questions. This category included 3 questions for knowing the interviewee's teaching year experience, age and the university graduated. The category of questions as to content and process included 13 main questions in total. What kind of technologies preschool teachers use, in which courses they use, for what purposes they use, what contributions technology provides in terms of teachers, children and curriculum, what kind of institutional support they get towards technology use, how the curriculum supports in terms of technology use, what the advantages and disadvantages of technology use are in preschool settings, why children need technology, what the positive and negative effects of technology use are on children, what contributions of technology use are in terms of educational life, what the description of technology can be, how the teacher's attitude toward technology is, and what the competence of the teacher is toward technology were the main questions of the interview protocol. Alternative questions were added for 4 different main questions. Additionally, prompts were used in 4 different questions to increase the clarity of the questions. Interview style, organization and questions were reviewed by a scholar who was working as professor in the department of educational sciences and expert on the qualitative research. In addition, two scholars from the field of instructional technology made suggestions on the interview questions. After getting feedbacks and revisions to be made, the final version of interview protocol was prepared.

\section{Data Collection Process}

The interviews were conducted with in-service preschool teachers one by one in different public and private preschools in Ankara district. Each interview was carried out in a room of the preschool where the teacher worked. Tape recorder was used to record the interview session by getting the permission of the interviewee. Interviews took 27 minutes on average.

\section{Data Analysis Technique}

The main purpose of the study was to understand in-service preschool teachers' thoughts about technology and technology use in early educational settings. Therefore, semi structured interviews were applied to understand preschool teachers' thinking in depth. For analyzing the data gathered via semi structured interviews, content analysis was preferred because it could enable researchers to reach common points regarding with the transcribed data. Content analysis is a technique enabling researcher to generally analyze written contents (Fraenkel \& Wallen, 2006). They also stated that "content analysis can be used in any context in which the researcher desires a means of systematizing and quantifying data" (p. 484). 
Bogdan and Biklen (2007) listed qualitative analysis steps as "working with the data, organizing them, breaking them into manageable units, coding them, synthesizing them, and searching for patterns" (p. 159). In light of this view, qualitative data analysis was started with organizing and working with the data for this study. In this step, all data gathered via interviews, were organized and transcribed to MS Word document. After organizing the data, the coding which bases the main process of content analysis was applied. Qualitative coding requires reviewing the data to find patterns and generating words or phrases to represent these patterns (Bogdan \& Biklen, 2007). Therefore, researcher coded all themes and sub themes. Axial coding was applied in the coding part of the analysis process because "axial coding enables researcher to group the codes according to conceptual categories that reflect commonalities among codes" (Marshall \& Rossman, 2011, p. 215). After finishing the coding process, themes emerged based on the axial coding. The researcher composed themes by considering the commonalities among codes created. After creating themes, the next step was making interpretations. The researcher tried to create meaningful connections by looking at the themes and related codes in this step. In the writing up step, researcher created all themes as title and reported all titles with quotations in accordance with the research question.

\section{Trustworthiness of the Study}

Trustworthiness of the study is related with reliability and validity issues. Reliability and validity are mainly seen as the criteria of a good qualitative research (Marshall \& Rossman, 2011). Since trustworthiness of the study is of great significance for the quality of the study, several strategies as to reliability and validity issues were taken into consideration.

\section{Intercoder Reliability}

According to Marshall and Rossman (2011), intercoder reliability means consistency between independent coders in terms of the definitions of each code. Creswell (2009) also stressed that intercoder agreement requires two or more coders coming together on the codes derived from the same part of the written content. Since coding is the main and essential activity of intercoder reliability, it is very important to find intercoder who has information about intercoder reliability and enough experience of coding. Therefore, a research assistant who conducted qualitative research studies and carried out qualitative coding participated to this study as an intercoder. She was a doctorate candidate at the department of Computer Education and Instructional Technology. Her main research field was instructional technology and she published several proceedings including qualitative research methods. She was also one of the intercoders in one of her studies in the past so that she was considered as experienced in qualitative coding. According to Miles and Huberman (1994), interrater reliability is calculated as below:

Intercoder reliability score $=$ Number of agreements $/$ (Number of agreements + Number of disagreements)

Miles and Huberman (1994) emphasized that the score which is at least .80 is accepted as good reliability. In this study, Miles and Huberman (1994)'s criteria was the basis on evaluating the intercoder reliability. 
In this study, intercoder reliability process was done for interviews conducted with 18 in-service preschool teachers to understand their thoughts about technology and technology use in early educational settings. Before starting the coding activity, purpose of the study and main research question were explained to the intercoder by the researchers. Researchers and the intercoder got an agreement about the process of coding like coding independently, comparing the codes and coding again if necessary. After transcribing the 18 interviews, an information rich transcription was selected by the researchers. The transcription together with a document including the research question and a short info about the study was sent to the intercoder via e-mail. The researchers and intercoder coded the transcription independently and finished coding in nearly 7 days. After finishing the coding, intercoders got together to compare the codes. Since the codes given were not consistent between the intercoders and intercoder reliability score was not enough to meet the criteria of good reliability score, the intercoders decided to code a new transcription. They also talked about the codes and tried to understand why they gave different codes to the same text. They also reached an agreement about the codes having close meanings. The same coding procedure was also applied for coding the second transcription from 18 interviews. After finishing the coding, the intercoders got together and compared the codes. Number of agreements including the codes with similar meanings and number of disagreements were calculated. Based on Miles and Huberman's (1994) formula, intercoder reliability score was calculated as .88 which was good level of reliability.

\section{Member Checking}

"Member checking determines the accuracy of the qualitative findings through taking the final report or specific descriptions or themes back to participants and determining whether these participants feel that they are accurate" (Creswell, 2009, p. 191). Creswell and Miller (2000) stated that sending transcriptions to the participants can be considered as a method for applying member checking. Hence, one of the transcriptions of 18 interviews was sent to the interviewee to check the raw data of the taped interview. The feedback of the interviewee was that the data was consistent with the taped interview and there was no need to change anything in the data.

\section{Findings}

To answer the research question, semi-structured interviews were carried out with 18 in-service preschool teachers. Eleven main themes emerged to understand their thoughts about technology and technology use in early educational settings. These themes were:

- Used Technologies

- Specific Characteristics of Technology

- Educational Use of Technology for Various Purposes

- Advantages of Technology for Children

- Potential Disadvantages of Technology for Children

- Turkish Preschool Curriculum in terms of Technology use

- Advantages of Technology for Teachers

- Teachers' Problems about Technology Use

- Pedagogical Problems

- Infrastructural Problems

- Teachers' Expectations about Technology Use 
- Technology Use Activities of Teachers

- Teachers' Thoughts about Technology Use

These themes were explained in detailed in the following section.

\section{Used Technologies}

All of teachers said that they use computers in preschool education. Additionally, 14 of 18 teachers declared using projector as a technology at school. For instance, a teacher stated:

If I need to present something to children, I make presentation via projector (PT10).

Overhead projector was another technology used by 10 of 18 teachers. 5 of 18 teachers said that they use TV as a technology at school. For instance, a teacher stated:

We also benefit from television. Children watch educational cartoons from television (PT10).

In conclusion, computer, projector, overhead projector and TV were the technologies that teachers used in preschool settings. It can be inferred from this finding that teachers prefer to use various technologies rather than using only computers.

\section{Specific Characteristics of Technology}

All of teachers mentioned the visual characteristic of technology. In addition, 15 of 18 teachers considered the audial characteristic of technology. For example, a teacher stated:

I use technology since its visual and audial sides take attention of children more and help remembering easily (PT8).

The concrete characteristic of technology was mentioned by 4 of 18 teachers. In addition, the affective and quick characteristics of technology were said by 3 of 18 teachers. Lastly, only 2 of 18 teachers considered the repetitive characteristic of technology.

In conclusion, teachers mentioned the visual, audial, concrete, affective, quick and repetitive characteristics of technology. It can be inferred from this finding that teachers are aware of the power of technology having multiple characteristics.

\section{Educational Use of Technology for Various Purposes}

12 of 18 teachers stated that they use technology in storytelling activities. For instance, a teacher said:

I like storytelling by using slides from the computer. I use it once per a week because it is a very effective method for children (PT10).

10 of 18 teachers said that they use technology in native language activities. A teacher gave an example to the native language activity as follow: 
I use technology especially in native language activities. I use it in the activity of preparation to literacy (PT6).

10 of 18 teachers also declared that they use technology in math activities. Technology use in cognitive activities was mentioned by 7 of 18 teachers. For instance, a teacher stated:

I can give cognitive objectives, such as counting and matching to children with educational games (PT6).

7 of 18 teachers also said that they use technology for listening music in an educational purpose for children. 6 of 18 teachers pointed out that they use technology in science and nature activities. Based on 6 of 18 teachers' responses, technology is used for teaching several concepts. According to 6 of 18 teachers, technology is used for presenting educational cartoons. 5 of 18 teachers stated that they use technology for presenting animations to children with educational purposes. 3 of 18 teachers also emphasized that they use technology for presenting art activities and documentaries.

In conclusion, teachers preferred to use technology in storytelling activities, native language activities, math activities, cognitive activities, music activities, science and nature activities, concept teaching, showing cartoons and animations, and art activities and documentaries. It can be inferred from this finding that teachers adapt technology into several classroom or curriculum based activities.

\section{Advantages of Technology for Children}

According to 15 of 18 teachers, technology takes attention of children. For instance, a teacher stated:

Watching television rather than only seeing in story book or listening the character with seeing its visual takes attention of children (PT4).

12 of 18 teachers said that technology allows visual learning of children. A teacher explained this as follow:

I showed from computer by supporting with visual things. They listened Beethoven while watching the pictures of Van Gogh. If I presented only pictures, it would not give that effect (PT7).

Based on the responses of 11 of 18 teachers, technology helps permanent learning. For instance, a teacher stated:

Children do not forget things that they watch from technology. For example, we have educational software CDs related with animals. They can carefully learn from that CDs and they do not forget (PT4).

7 of 18 teachers stated that technology improves cognitive skills of children. 7 of 18 teachers also said that technology addresses many senses of children. According to 6 of 18 teachers, technology considers individual differences. Improving psychomotor skills was another advantage of technology and stated by 6 teachers. 6 of 18 teachers mentioned about improving motivation as an advantage of technology for children. Besides, 5 teachers emphasized that technology adapts children to future easily. In addition, 5 of 18 teachers pointed out that technology improves the curiosity of children. 4 of 18 teachers also stated that technology 
improves hand-eye coordination of children. Moreover, 3 teachers pointed out that improving self-confidence of children and allowing learning by doing were other advantages of technology for children. Furthermore, rehearsal learning, helping children transfer their knowledge to real life and improving creativity of children were the other advantages of technology for children and only stated by 2 teachers.

In conclusion, based on teachers' responses, taking attention of children, allowing visual learning, helping permanent learning, improving cognitive skills, addressing many senses of children, considering individual differences, improving psychomotor skills, improving motivation, adapting children easily to future, improving the curiosity, improving hand-eye coordination, improving self-confidence, allowing learning by doing, rehearsal learning, helping children transfer their knowledge to real life and improving creativity were the advantages of technology. It can be inferred by considering these advantages that teachers believe the support and contribution of technology to children in many areas.

\section{Potential Disadvantages of Technology for Children}

According to 11 of 18 teachers, preventing socializing was a disadvantage of technology for children. A teacher explained this as follow:

Technology prevents building communication of children with their friends. It is clear that children do not play games outside so much. They generally spend their times at home and they are interested in indoor activities (PT11).

Based on the responses of 5 teachers, technology also prevents social play. For instance, a teacher stated:

Children play with computers or watch television rather than playing outside (PT6).

Besides, 5 teachers pointed out that children spend excessive amount of time while using technology. In addition, 4 teachers emphasized that children face with undesired things while using technology. A teacher explained this by saying:

Many of the children know how to connect to internet and they can face with undesired things on the internet (PT2).

Besides, 4 teachers mentioned about psychological problems as one of the disadvantages of technology for children. Additionally, uncontrolled use of technology was another disadvantage of technology for children and stated by 3 teachers. 3 of 18 teachers also stated that technology use can cause health problems for children. Moreover, speech problems and becoming addict were the other disadvantages of technology use for children and stated by 2 teachers as well.

In conclusion, preventing socializing, preventing social play, spending excessive amount of time, facing with undesired things, psychological problems, uncontrolled use of technology, causing health problems, speech problems and becoming addict were the disadvantages of technology mentioned by teachers. It can be reached from these disadvantages that teachers are aware of the problems in case of inappropriate technology use. 


\section{Turkish Preschool Curriculum in terms of Technology Use}

According to 13 of 18 teachers, Turkish preschool curriculum does not include goals and objectives for using technology. For instance, a teacher stated:

There is no any objective including the word of technology. Tools can be exist but there is no any goal and objective related with technology (PT2).

Additionally, 9 of 18 teachers emphasized that the curriculum is lack of guidance in use of technology. A teacher explained this as follow:

There is no much guidance. This can be caused from the limited numbers of computers. There are some statements like including technology into education or activities but they are only written statements which are not practical (PT5).

Besides, 6 teachers pointed out that there is a necessity of detailed goals and objectives of technology use in the curriculum. In addition, 6 of 18 teachers stated that there is a necessity of having standardization in the curriculum about technology use. Moreover, lack of detailed explanations as to technology use in the curriculum was another statement for the theme of Turkish preschool curriculum in terms of technology use and stated by 4 teachers.

In conclusion, not including goals and objectives for using technology, lack of guidance in use of technology, necessity of detailed goals and objectives of technology use, necessity of having standardization in curriculum about technology use and lack of detailed explanations as to technology use were the views of teachers about technology use in Turkish Preschool Curriculum. It can be inferred from these findings that teachers consider the curriculum as insufficient in terms of statements about technology use.

\section{Advantages of Technology for Teachers}

According to 15 of 18 teachers, technology makes the teacher's job easier. For instance, a teacher stated:

Quick access makes my job easier. On the other hand, I need to search, find pictures and show them to children. But, I can find them from internet easily and get colored copy of the pictures from the printer. So, it becomes a very easy process (PT4).

In addition, 7 of 18 teachers pointed out that technology allows teacher to use different materials. A teacher explained this as follow:

I use technology as different educational materials. It provides a different teaching environment to me. Education becomes successful if we give so many different stimuli to children (PT12).

Using technology for acceleration of teaching was another advantage of technology for teachers and stated by 6 teachers. Besides, 6 teachers pointed out that technology helps teacher in classroom management. For instance, a teacher stated:

You create a magical atmosphere in the classroom environment with the help of technology. It takes the attention of all children immediately. Hence, you don't 
need to concentrate them one by one. Technology becomes a magic tool taking attention of children altogether at the same time (PT11).

Lastly, saving time of teachers was the other advantage of technology for teachers and stated by only 3 teachers.

In conclusion, makes the teacher's job easier, allowing teacher to use different materials, acceleration of teaching, helping teacher in classroom management and saving time were the advantages of technology for teachers. It can be inferred by considering these advantages that technology supports teaching activities in preschool education.

\section{Teachers' Problems about Technology Use}

\section{Pedagogical Problems}

According to 6 of 18 teachers, they have difficulties in one to one interaction with technology for all children. For example, a teacher stated:

There is only one computer in the classroom and all of the children want to play with the computer. So, this situation creates a problem (PT3).

In addition, inadequacy in teacher knowledge of technology use and limited technology use skills were the other pedagogical problems of teachers about technology use and stated by 4 teachers.

\section{Infrastructural Problems}

7 of 18 teachers declared that there is a lack of high quality resources. A teacher explained this as follow:

There are a lot of CDs. Each publisher produces educational CDs but they are not usable. CDs include some things but I never use them (PT6).

Additionally, 6 of 18 teachers pointed out that there are difficulties in having a computer for each class. For example, a teacher said:

I can make limited individual study with children by using technology because we don't have computers in the classrooms (PT7).

Besides, 5 teachers emphasized that there is a lack of projector in classrooms. 5 of 18 teachers also declared that classrooms are crowded. Lastly, lack of computer lab was the other infrastructural problem of technology use and stated by only 2 teachers.

In conclusion, having difficulties in one to one interaction, inadequacy in teacher knowledge of technology use and limited technology use skills were the pedagogical problems about technology use. On the other hand, lack of high quality resources, having a computer for each class, lack of projector in classrooms, crowded classrooms and lack of computer lab were the infrastructural problems about technology use. It can be reached from these findings that teachers face with problems not only related with their personal technology use skills but also schools' technical capacities. 


\section{Teachers' Expectations about Technology Use}

Based on the responses of 16 of 18 teachers, teachers expect professional development courses of advanced technology use in preschool education. For instance, a teacher stated:

In fact, I would like to get informed about computer programs especially graphical programs. I would like to learn programs about how to present pictures in different ways. I would also like to learn computer programming (PT12).

Additionally, 16 of 18 teachers expect limitations on technology use for children. A teacher explained this as follow:

I also use technology at school or in my activities. Technology use can be limited based on time limitation or the level of reaching an objective (PT9).

Besides, 12 of 18 teachers stated that there is a need for teacher control in technology use. For instance, a teacher said:

In my opinion, technology should be used as useful for children and there should be a teacher control in using technology for children (PT12).

11 of 18 teachers also emphasized that there is a need for parental control in technology use. A teacher's view for this expectation was as follow:

Children think quickly and they are aware of everything. The parental control is very important at this point (PT4).

Besides, 10 of 18 teachers pointed out that there is a necessity of using technology in an appropriate way. For instance, a teacher stated:

Technology should be used for teaching purpose. It shouldn't be used for watching educational cartoons although it is very common in preschool education. Using technology for spending time is also very common. That is, teachers use technology as an entertainment tool rather than using for developing themselves or finding new methods of teaching for children (PT12).

Besides, 10 of 18 teachers declared that there is a need for technology integrated courses. For instance, a teacher told:

I will chat with children who don't have any idea about the topic. If I don't present anything about the topic, children's attention won't be taken and they who are in a specific developmental level cannot give a meaning to the topic. Hence, I need to use a presentation or a cartoon to teach the topic (PT9).

7 of 18 teachers stated that there is a need for teaching how to use technology. 7 of 18 teachers also emphasized that there is a need for giving training to parents on how children use technology appropriately. Besides, 6 teachers pointed out that there is a necessity of having materials suitable for children. For instance, a teacher said:

Children should spend their times with softwares suitable for them. For example, let's consider the topic of traffic. There will be a traffic game and the child will see and chat with his/her friend. He/She will practice stopping the car in red light or moving the car in green light in that game. So, technology will be used in a right way and the child will learn how to use computer appropriately (PT4). 
Moreover, 5 teachers stated that there is a need for using different kind of technologies. Furthermore, 4 teachers declared that there is a necessity of computer lab. Lastly, need for a computer in each classroom, need for projector in classrooms and need for assigning computer teachers were the other expectations of teachers about technology use and stated by only 3 teachers.

In conclusion, professional development courses of advanced technology use in preschool education, limitations on technology use for children, teacher and parental control in technology use, using technology in an appropriate way, technology integrated courses, teaching how to use technology, giving training to parents on how children use technology appropriately, having materials suitable for children, using different kind of technologies, having computer lab, having computer in each classroom, having projector in classrooms and assigning computer teachers were teachers' expectations about technology use. Based on these findings, teachers expect from not only teachers but also parents to lead children to use technology appropriately. Findings also indicate that preschools need to be equipped with adequate computers or projectors.

\section{Technology Use Activities of Teachers}

According to 13 of 18 teachers, they search for educational softwares or programs suitable for children. For instance, a teacher stated: I used internet too much to find programs suitable for children. For instance, I don't know how to prepare animations in flash but I took a few animations from my friends knowing how to prepare them. But, I generally try to find them from internet (PT17).

Additionally, 13 of 18 teachers stated that they use technology based on their choice. A teacher explained this as follow:

Technology use is the decision of teacher. Teacher decides to use computer or projector. There is no any statement forcing teacher to use technology in goals and objectives of the curriculum (PT2).

Besides, 12 of 18 teachers emphasized that they use technology to support teaching concepts or objectives. For example, a teacher stated:

For example, we read from the books of The Scientific and Technological Research Council of Turkey and we make visual conversations with children. Then, we draw things that we read, look for the things at the garden, etc. While doing these things, I also show video about the things that we read. For instance, I show a web site about birds and children see different birds and listen to their sounds. This is very pleasant for children and it is also effective on learning (PT7).

Besides, 10 of 18 teachers pointed out that they lead children to use computers at school. For instance, a teacher's view for this activity was as follow:

We use computer in an individual way for drawing or designing something in paint (PT7). 
Moreover, 7 of 18 teachers declared that they make pre-lesson preparation of electronic materials. 7 of 18 teachers also stated that they present stories or several topics on power point. For instance, a teacher told:

I can only prepare power point slides. I add pictures to the slides based on the story or the topic that I chose before. I make the slides interactive with a few questions by giving clapping sound when children find the right answer of the question (PT18).

Lastly, using own personal computer at school and guidance of teacher at the beginning of technology use were the other technology use activities and stated by 4 teachers.

In conclusion, searching for educational softwares or programs suitable for children, using technology based on their choice, using technology to support teaching concepts or objectives, leading children to use computers at school, making pre-lesson preparation of electronic materials, presenting stories or several topics on power point, using own personal computer at school and guidance of teacher at the beginning of technology use were teachers' technology use activities. Based on the findings, teachers mostly use technology for supporting teaching and learning activities.

\section{Teachers' Thoughts about Technology Use}

According to 13 of 18 teachers, there is a necessity of using technology in preschool education. For instance, a teacher stated:

Technology must be used in preschool education and it must be considered at specific parts of education based on the age group characteristics of children (PT7).

Additionally, 11 of 18 teachers considered technology as a tool making life easier. A teacher explained this as follow:

I define technology as a tool making life easier, entertaining and providing information (PT11).

Besides, 7 teachers called computer as the first idea of technology. They remembered computer when asking what they think about the specific definition or example of technology. Moreover, 6 of 18 teachers emphasized that there are high technology use capabilities of today's children. For example, a teacher said:

Children know how to use Ipad and Iphone because of their social environment.

They do not need to be taught about these technologies. They know about technology more than me and other teachers. They have a variety of technologies at home (PT8).

Besides, based on the responses of 6 teachers, technology is a tool rather than a goal. Furthermore, 6 of 18 teachers pointed out that teacher is a guide in technology use. For instance, a teacher stated:

I guided children and helped them use technology. Some of them are used to handling the mouse and they can build coordination. However, some of them do not use so much. Hence, I helped them (PT6). 
Lastly, wrong parental guidance was the other thought about technology use and stated by 4 teachers. For instance, a teacher stated:

Parents allow children to use computer and TV for playing games and watching cartoons. This is not a correct way of technology use because I support technology use activities of children playing individually to develop their creativity (PT9).

In conclusion, necessity of using technology in preschool education, considering technology as a tool making life easier, computer as the first idea of technology, high technology use capabilities of today's children, technology as a tool rather than a goal, teacher as a guide in technology use and wrong parental guidance were thoughts' of teachers toward technology and technology use. It can be inferred from these findings that teachers give importance to technology use for children in appropriate guidance of teachers and parents.

\section{Discussion}

Semi-structured interviews were carried out to understand in-service preschool teachers' thoughts about technology and technology use in early educational settings. Based on the findings, computers were the most used technologies in preschool settings. Similar to this finding, Towns (2010) found that early childhood teachers are agreed on using computers in classrooms. On the other hand, projector, overhead projector and TV were the other used technologies in early educational settings. For specific characteristics of technology, visuality and audio were the most emphasized characteristics of technology. It can be inferred from these findings that teachers use different kind of technologies in preschool education.

According to the findings, teachers preferred to use technology mostly in storytelling and language activities. Similar to this finding, Marsh et al. (2005) stated that new technologies have been used in language and literacy activities by the majority of early childhood educators. Findings revealed that technology has also been used in math and cognitive activities by preschool teachers. This finding reaffirmed that teachers have a desire to improve cognitive skills of children by including computers into activities (Yurt \& Cevher-Kalburan, 2011). Listening music activity was also stated by teachers to use technology for. Similarly, Yurt and CevherKalburan (2011) emphasized that computers are mostly included into music activities by early childhood teachers. Findings also showed that teachers use technology in science and nature activities, teaching several concepts, presenting educational cartoons, animations, art activities and documentaries. It can be reached from these findings that preschool teachers use technology/computers for a variety of educational activities.

For the advantages of technology, the majority of teachers stated that technology takes attention of children. Similarly, Gok et al. (2011) found that information technologies positively affect interest and attention levels of children when these technologies are used appropriately. Additionally, the contribution of technology to visual and permanent learning was also stated by the majority of teachers. Similar to this finding, Marsh et al. (2005) pointed out that involving new technologies into curriculum related activities supports desires of children towards learning. Improving cognitive skills was another advantage of technology use for children. This is similar to Tsitouridou and Vryzas's (2004) statement that the majority of teachers believe the importance of computer use to enhance cognitive development of children. Moreover, addressing many senses of children and considering individual differences were stated by teachers as advantages of technology use for children. Teachers also emphasized that 
technology use improves psychomotor skills of children. In parallel to this finding, Tsitouridou and Vryzas (2004) declared that teachers accept the support of computer use to psychomotor development of children. Improving motivation was another advantage of technology use for children. Similarly, Marsh et al. (2005) stressed that new technologies improve motivation of children toward learning activities. Furthermore, teachers stated that technology use adapts children easily to future, improves curiosity and enhances hand-eye coordination of them. Findings also showed that technology use improves self confidence of children. Similarly, Blackwell et al. (2014) mentioned about the importance of confidence in technology use. Lastly, allowing learning by doing, rehearsal larning, helping children transfer their knowledge to real life and improving creativity of children were the other advantages of technology use for children. It can be concluded from these findings that technology use has several advantages for children from the view of preschool teachers.

For the potential disadvantages of technology for children, the majority of teachers stated that technology prevents socializing. This is similar to Wood, Specht, Willoughby and Mueller's (2008) finding that computers may prevent social development of children. Preventing social play and spending excessive amount of time were other disadvantages of technology use for children. Marsh et al. (2005) mentioned the worries about the time children spend on technology related activities. Facing with undesired things, creating psychological problems, uncontrolled use, causing health problems, speech problems and becoming addict were the other findings as to the potential disadvantages of technology use for children. It can be concluded from these findings that in-service preschool teachers are aware of the threats which can be caused by inappropriate technology use.

Turkish preschool curriculum in terms of technology use was another thematic finding of semistructured interviews with in-service preschool teachers. It can be reached from the findings that Turkish preschool curriculum does not include specific explanations or instructions as to integrating technology into preschool education. Findings also imply that teachers expect explicit statements about how to use technologies in various activities of children.

According to the findings of advantages of technology for teachers, the majority of teachers stated that technology makes teachers' job easier. Additionally, teachers pointed out that technology allows teacher to use different materials. Similarly, teachers use computers to support curriculum related activities (Yurt \& Cevher-Kalburan, 2011). Moreover, using technology for acceleration of teaching, helping teacher in classroom management and saving time of teachers were the other findings as to the advantages of technology for teachers. It can be concluded from these findings that technology supports teaching activities of teachers and helps them control and guide children in classroom activities.

Teachers also mentioned the problems about technology use. In pedagogical problems, teachers stated that there are difficulties in one to one interaction with technology for all children. Additionally, teachers mentioned the inadequacy in teacher knowledge of technology use. Tsitouridou and Vryzas (2004) explained the importance of teacher knowledge of technology use by saying that "teachers with extensive knowledge and experience with computers believe that the introduction of computers into early childhood education is an urgent priority" (p. 40). Limited technology use skills was the other finding as to teachers' pedagogical problems about technology use. According to Chen and Chang (2006), "teacher proficiency in technology integration is a critical determinant of the educational benefits children gain from using computers" (p. 178). Similarly, Keengwe and Onchwari (2009) found that teachers have worries 
about their technology use skills to meet today's children expectations. In infrastructural problems, nearly half of the teachers emphasized lack of high quality resources. Similarly, teachers develop their own materials or softwares to use in early educational settings because of lack of resources (Kalaš, 2010). Nikolopoulou and Gialamas (2009) also supported this finding by saying that necessary and suitable resources should be integrated into early childhood classrooms. Difficulties in having a computer for each classroom and lack of projector in classrooms were other findings as to infrastructural problems about technology use. These findings reaffirm that necessary equipment is not provided to the majority of teachers when they are in need of using new technologies (Kabadayi, 2006). Teachers also stated that crowded classrooms and lack of computer lab at schools were the other findings as to infrastructural problems about technology use. It can be concluded from these findings that teachers have problems not only causing from themselves but also coming from schools or educational system.

For teachers' expectations about technology use, the majority of teachers stated that there is a need for professional development courses of advanced technology use. This finding is similar to the literature explaining that teacher training programs allow teachers to effectively integrate ICT into early educational settings (Chen \& Chang, 2006; Cox \& Marshall, 2007; Gialamas \& Nikolopoulou, 2010; Nikolopoulou \& Gialamas, 2009). Additionally, the majority of teachers emphasized that there is a need for limitations on technology use for children. It can be inferred from this finding that teachers are in favor of limited technology use for children rather than excessive use. Need for teacher control and need for parental control in technology use were other findings as to the expectations of teachers about technology use. This finding reaffirms that "the appropriate use of computer technology under the guidance of teacher or parent can assist the holistic development of the child. (Tsitouridou \& Vryzas, 2004, p. 40). Moreover, most of the teachers declared that there is a necessity of using technology in an appropriate way. This is similar to the finding that appropriate technology use of early childhood teachers supports children's involvement into several classroom activities (Gok et al., 2011). Need for technology integrated courses, need for teaching how to use technology, necessity of having materials suitable for children and need for using different kind of technologies were other findings as to the expectations of teachers about technology use. It can be inferred from these findings that in-service preschool teachers have a desire to integrate technologies into early educational settings. The findings indicated that teachers expect appropriate materials or softwares which are ready to use for children in preschool education. Teachers also stressed that there is a need for giving training to parents on how children use technology appropriately. This was an important finding because teachers believe that parents do not guide children in technology use correctly. Necessity of computer lab, need for a computer in each classroom and need for projector in classrooms were the other findings related with teachers' expectations about technology use. It can be concluded from these findings that teachers expect technologically equipped classrooms to integrate technologies into preschool education effectively. Lastly, some teachers stated that there is a need for assigning computer teachers. They believe that computer teachers can be more helpful to children in giving technology related activities.

According to the findings based on technology use activities of teachers, the majority of teachers stated that teachers search for educational softwares or programs suitable for children, use technology based on their choices, use technology to support teaching concepts or objectives and lead children to use computers at school. These findings are similar to the statement that "in the classroom, teachers adapt computer use to accommodate children's varying levels of skills, different personal interests, and optimal social groupings" (Chen \& Chang, 2006, p. 181). Pre-lesson preparation of electronic materials and presenting stories or several topics on power 
point were other findings as to technology use activities of teachers. Similarly, Kalaš (2010) emphasized that since resources for using in early childhood education are limited, teachers tend to produce their own materials or softwares to use in early educational classrooms. Some of the teachers also stated that they use own personal computer at school and they guide children at the beginning of technology use. It can be inferred from these findings that there is a limited number of computers at schools or computers are not in a good condition. Findings also imply that teachers spend an effort to introduce technology to children.

Teachers also explained their thoughts about technology use. The majority of teachers stated that there is a necessity of using technology in preschool education. Similar to this finding, there are several statements in the literature indicating that computers or new technologies should be included in early childhood education and teachers have a positive attitude towards technology use in early childhood education (Chen \& Chang, 2006; Nikolopoulou \& Gialamas, 2009; Tsitouridou \& Vryzas, 2004; Yurt \& Cevher-Kalburan, 2011). In addition, technology as a tool making life easier and computer as the first idea of technology were other findings as to teachers' thoughts about technology use. It can be inferred from these findings that in-service preschool teachers mostly consider computers as technology and define technology as a helpful tool in daily life. Teachers also stated that today's children have high technology use capabilities. In parallel to this finding, Tsitouridou and Vryzas (2004) mentioned about the familiarity of children with computers to integrate computers into early childhood education. Moreover, technology as a tool rather than a goal was another important finding about teachers' thoughts of technology use. Similarly, Chen and Chang (2006) emphasized on computer as a tool allowing teachers to help in learning activities. Teachers also declared that they guide children in technology use. This is similar to the finding that "the teachers did acknowledge that they were guiding children to use programs that were not only age appropriate, but also developmentally appropriate" (Towns, 2010, p. 83). Lastly, wrong parental guidance was the other finding as to teachers' thoughts about technology use.

\section{Conclusion}

In summary, the majority of teachers have positive intentions about integrating technology into early childhood education. They also expect support from not only curriculum but also schools about using technology for children in an appropriate way. Teachers have a desire to include new technologies in early educational settings if they are organized and well developed. Besides, teachers, in general, are aware of both advantages and disadvantages of technology use. However, they focus on the advantages more than the problems caused by technology use. Teachers also use technology in several classroom activities in preschools. Finally, it can be said that preschool teachers' desires and expectations should be taken into account in technology integration practices.

\section{Recommendations}

This study was about understanding in-service preschool teachers' thoughts about technology and technology use in early educational settings. At the end of the study, several findings as to views of preschool teachers toward technology and technology practices emerged. Based on the results, several recommendations can be listed as follow: 
- Preschool teachers' needs and expectations as to technology use in preschool education should be taken into consideration by policy makers especially in revising preschool curriculum in terms of integrating technology into preschool education.

- Preschool teachers' views and expectations as to technology practices should yield strategies for instructional designers to shape early educational settings.

- School managers should consider preschool teachers' problems regarding with technology integration into early educational settings.

- Observation studies should be conducted to further elaborate technology use practices of in-service preschool teachers.

- Children should be added to long term research studies to better understand the effectiveness of technology activities in preschool education.

\section{References}

Atay-Turhan, T., Koc, Y., Isiksal, M., \& Isiksal, H. (2009). The new Turkish early childhood teacher education curriculum: A brief outlook. Asia Pacific Education Review, 10, 345356.

Blackwell, C. K., Lauricella, A. R., \& Wartella, E. (2014). Factors influencing digital technology use in early childhood education. Computers \& Education, 77, 82-90.

Bogdan, R. C. \& Biklen, S. K. (2007). Qualitative research for education: An introduction to theory and methods (5th ed.). Boston: Allyn \& Bacon.

Bolstad, R. (2004). The role and potential of ICT in early childhood education. A review of New Zealand and international literature. Wellington: Ministry of Education.

Brenner, M. E. (2006). Interviewing in educational research. In J. L. Green, G. Camilli, \& P. B. Elmore (Eds.), Handbook of complementary methods in education research (pp. 357370). Mahwah, NJ: Lawrence Erlbaum.

Chen, J. \& Chang, C. (2006). Using computers in early childhood classrooms: Teachers' attitudes, skills and practices. Journal of Early Childhood Research, 4(2), 169-188.

Cox, M. \& Marshall, G. (2007). Effects of ICT: Do we know what we should know? Education and Information Technologies, 12(2), 59-70.

Creswell, J. W. (2009). Research design: Qualitative, quantitative, and mixed methods approaches (3rd ed.). Thousand Oaks, CA: Sage.

Creswell, J. W. \& Miller, D. L. (2000). Determining validity in qualitative inquiry. Theory into Practice, 39(3), 124-130.

Fraenkel, J. R. \& Wallen, N. E. (2006). How to design and evaluate research in education (6th ed.). New York, NY: McGraw-Hill.

Gialamas, V. \& Nikolopoulou, K. (2010). In-service and pre-service early childhood teachers' views and intentions about ICT use in early childhood settings: a comparative study. Computers \& Education, 55, 333-341.

Gok, A., Turan, S., \& Oyman, N. (2011). Okul oncesi ogretmenlerinin bilisim teknolojilerini kullanma durumlarina iliskin gorusleri. Pegem Egitim ve Ogretim Dergisi, 1(3), 59-66. 
Isikoglu, N., Basturk, R., \& Karaca, F. (2009). Assessing in-service teachers' instructional beliefs about student-centered education: A Turkish perspective. Teaching and Teacher Education, 25, 350-356.

Kabadayi, A. (2006). Analyzing pre-school student teachers' and their cooperating teachers' attitudes towards the use of educational technology. Turkish Online Journal of Educational Technology, 5(4). Retrieved on 15 June 2015 from www.tojet.net

Kalas, I. (2010). Recognizing the potential of ICT in early child education. Analytical Survey. Moscow: UNESCO Institute for Information Technologies in Education.

Keengwe, J. \& Onchwari, G. (2009). Technology and early childhood education: a technology integration professional development model for practicing teachers. Early Childhood Education Journal, 37(3), 209-218.

Mangen, A. (2010). Point and click: Theoretical and phenomenological reflections on the digitization of early childhood education. Contemporary Issues in Early Childhood, 11(4), 415-431.

Marsh, J., Brooks, G., Hughes, J., Ritchie, L., Roberts, S. \& Wright, K. (2005) Digital beginnings: young children's use of popular culture, media and new technologies. Retrieved on 22 July 2015 from http://www.digitalbeginnings.shef.ac.uk/final-report.htm

Marshall, C. \& Rossman, G. B. (2011). Designing qualitative research (5th ed.). Thousand Oaks, CA: Sage.

Miles, M. B. \& Huberman, A. M. (1994). An expanded sourcebook: Qualitative data analysis (2nd ed.). Thousand Oaks, CA: Sage.

MoNE. (2013). Okul oncesi egitim programi. Retrieved on 14 May 142015 from http://tegm. meb.gov.tr/dosya/okuloncesi/ooproram.pdf

MoNE. (2014). National Education Statistics. Formal Education 2013/'14. Retrieved on 16 June 2015 from http://sgb.meb.gov.tr/www/milli-egitim-istatistikleri-orgun-egitim-20132014/icerik/95

Nikolopoulou, K. \& Gialamas, V. (2009). Investigating pre-service early childhood teachers' views and intentions about integrating and using computers in early childhood settings: Compilation of an instrument. Technology, Pedagogy and Education, 18(2), 201-219.

Oguz, E., Ellez, A. M., Akamca, G. O., Kesercioglu, T. I., \& Girgin, G. (2011). Early childhood teacher candidates' attitudes towards computer and computer assisted instruction. Elementary Education Online, 10(3), 934-950. Retrieved on 20 May 2015 from http://ilkogretim-online.org.tr/

Onkol, F. L., Zembat, R., \& Balat, G. U. (2011). Computer use attitudes, knowledge and skills, habits and methods of preschool teachers. Procedia Computer Science, 3, 343-351. Retrieved on 15 June 2015 from http://www.sciencedirect.com/science/article/pii/ S1877050910004333

Stipek, D. J. \& Byler, P. (1997). Early childhood education teachers: Do they practice what they preach? Early Childhood Research Quarterly, 12, 305-325.

Towns, B. (2010). Computer education and computer use by preschool educators (Order No. 3403175). Available from ProQuest Dissertations \& Theses Global. (365702854). Retrieved on 22 June 2015 from http://search.proquest.com/docview/365702854? accountid $=13014$ 
Tsitouridou, M. \& Vryzas, K. (2004). The prospect of integrating ICT into the education of young children: The views of Greek early childhood teachers. European Journal of Teacher Education, 27(1), 29-45.

Wood, E., Specht, J., Willoughby, T., \& Mueller, J. (2008). Integrating computer technology in early childhood education environments: issues raised by early childhood educators. Alberta Journal of Educational Research, 54(2), 210-228.

Yurt, O. \& Cevher-Kalburan, N. (2011). Early childhood teacher's thoughts and practices about the use of computers in early childhood education. Procedia Computer Science, 3, 15621570. Retrieved on 10 June 2015 from http://www.sciencedirect.com/science/article/ pii/S1877050911000512\#

Correspondence: Nuri Kara, Assistant Professor, Department of Computer Education and Instructional Technologies, Faculty of Education, Girne American University, Girne, North Cyprus 